\author{
Marquette University \\ e-Publications@Marquette
}

College of Education Faculty Research and

Publications

Education, College of

$7-2006$

\title{
Perceived Family Support, Acculturation, and Life Satisfaction in Mexican American Youth: A Mixed-Methods Exploration
}

Lisa Edwards

Marquette University, lisa.edwards@marquette.edu

Shane J. Lopez

University of Kansas Main Campus

Follow this and additional works at: https://epublications.marquette.edu/edu_fac

Part of the Education Commons

\section{Recommended Citation}

Edwards, Lisa and Lopez, Shane J., "Perceived Family Support, Acculturation, and Life Satisfaction in Mexican American Youth: A Mixed-Methods Exploration" (2006). College of Education Faculty Research and Publications. 47.

https://epublications.marquette.edu/edu_fac/47 


\title{
Perceived Family Support, Acculturation, and Life Satisfaction in Mexican American Youth: A Mixed-Methods Exploration
}

\author{
Lisa M. Edwards \\ Department of Counseling and Educational Psychology \\ Marquette University \\ Milwaukee, WI \\ Shane J. Lopez \\ Psychology and Research in Education, University of Kansas \\ Lawrence, $K S$
}

In this article, the authors describe a mixed-methods study designed to explore perceived family support, acculturation, and life satisfaction among 266 Mexican American adolescents. Specifically, the authors conducted a thematic analysis of open-ended responses to a question about life satisfaction to understand participants' perceptions of factors that contributed to their overall satisfaction with life. The authors also conducted hierarchical regression analyses to investigate the independent and interactive contributions of perceived support from family and Mexican and Anglo acculturation orientations on life satisfaction. Convergence of mixed-methods findings demonstrated that perceived family support and Mexican orientation were significant predictors of life satisfaction in these adolescents.

Implications, limitations, and directions for further research are discussed. 
Psychologists have identified and studied a number of challenges faced by Latino youth (e.g., juvenile delinquency, gang activity, school dropout, alcohol and drug abuse), yet little scholarly time and energy have been spent on exploring how these adolescents successfully navigate their development into adulthood or how they experience well-being (Rodriguez \& Morrobel, 2004). Researchers have yet to understand the personal characteristics that play a role in Latino adolescents' satisfaction with life or how certain cultural values and/or strengths and resources are related to their well-being. Answers to these questions can begin to provide counseling psychologists with a deeper understanding of how Latino adolescents experience wellbeing, which can, in turn, hopefully allow researchers to work to improve well-being for those who struggle to find it.

Latino ${ }^{1}$ youth are a growing presence in most communities within the United States. The U.S. Census Bureau projects that by the year $2010,20 \%$ of young people between the ages of 10 and 20 years will be of Hispanic origin. Furthermore, it is projected that by the year 2020, one in five children will be Hispanic, and the Hispanic adolescent population will increase by $50 \%$ (U.S. Census Bureau, 2000, 2001). Whereas adolescence is a unique developmental period for all youth, Latino adolescents in particular may face additional challenges as a result of their ethnic minority status (Vazquez Garcia, Garcia Coll, Erkut, Alarcon, \& Tropp, 2000). These youth generally have undergone socialization experiences of their Latino culture (known as enculturation) and also must learn to acculturate to the dominant culture to some degree (Knight, Bernal, Cota, Garza, \& Ocampo, 1993). Navigating the demands of these cultural contexts can be challenging, and yet many Latino youth experience well-being and positive outcomes. The increasing numbers of Latino youth, along with the counseling psychology field's imperative to provide culturally competent services, require that professionals continue to understand the full range of psychological functioning for members of this unique population.

Counseling psychologists have continually emphasized the importance of well-being and identifying and developing client strengths in theory, research, and practice (Lopez et al., 2006; Walsh, 2003). This commitment to understanding the whole person, including internal and contextual assets and challenges, has been one hallmark

Journal of Counseling Psychology, Vol. 53, No. 3 (July 2006): pg. 279-287. DOI. This article is @ American Psychological Association and permission has been granted for this version to appear in e-Publications@Marquette. American Psychological Association does not grant permission for this article to be further copied/distributed or hosted elsewhere without the express permission from American Psychological Association. 
of the field (Super, 1955; Tyler, 1973) and has influenced a variety of research about optimal human functioning (see D. W. Sue \& Constantine, 2003). More recent discussions in this area have underscored the importance of identifying and nurturing cultural values and strengths in people of color (e.g., family, religious faith, biculturalism), being cautious to acknowledge that strengths are not universal and may differ according to context or cultural background (Lopez et al., 2006; Lopez et al., 2002; D. W. Sue \& Constantine, 2003), and may be influenced by certain within-group differences such as acculturation level (Marin \& Gamba, 2003; Zane \& Mak, 2003).

As scholars respond to the emerging need to explore strengths among Latino youth, the importance of investigating these resources and values within a cultural context is evident. Understanding how Latino adolescents experience well-being from their own perspectives and vantage points is integral, as theories from other cultural worldviews may not be applicable to their lives (Auerbach \& Silverstein, 2003; Lopez et al., 2002; D. W. Sue \& Constantine, 2003). Furthermore, it is necessary to continue to test propositions about the role of certain Latino cultural values, such as the importance of family, in overall well-being. Given that many Latino adolescents today navigate bicultural contexts and adhere to Latino traditions and customs to differing degrees (Romero \& Roberts, 2003), it is likely that the role family plays in adolescent well-being is complex and influenced by individual differences such as acculturation. In this study, we sought to explore the relationships between these variables by focusing specifically on perceived family support, life satisfaction, and acculturation among Mexican American youth.

\section{Perceived Family Support, Acculturation, and Life Satisfaction Among Latino Youth}

The importance of family has been noted as a core Latino cultural value (Castillo, Conoley, \& Brossart, 2004; Marin \& Gamba, 2003; Paniagua, 1998; Sabogal, Marin, Otero-Sabogal, Marin, \& PerezStable, 1987). Familismo (familism) is the term used to describe the importance of extended family ties in Latino culture as well as the strong identification and attachment of individuals with their families (Triandis, Marin, Betancourt, Lisansky, \& Chang, 1982). Familism is 
not unique to Latino culture and has been noted as an important value for other ethnic groups such as African Americans, Asian Americans, and American Indians (Cooper, 1999; Marin \& Gamba, 2003). Nevertheless, it is considered a central aspect of Latino culture, and in some studies, it has been shown to be valued by Latino individuals more than by non-Latino Whites (Gaines et al., 1997; Marin, 1993; Mindel, 1980).

In a study of familismo among Latino adolescents, Vazquez Garcia et al. (2000) found that the length of time youth had been in the United States did not affect their adherence to the value of familismo. These results demonstrated that the longer adolescents had been in the United States, the less they endorsed the value of respeto (respect), but their endorsement of familismo did not change. These findings highlight the central and enduring role that family plays in Latino culture, for both adults and adolescents.

Most research about familismo has assessed the attitudinal dimension of this construct, which has been hypothesized to include a sense of perceived support from family, family obligations, solidarity, reciprocity, and family as referents (Marin, 1992; Marin \& Gamba, 2003; Sabogal et al., 1987). It appears that perceived family support may be the key component of this value, as evidenced by research with Latino adults that investigated differences in aspects of familismo across acculturation levels. For example, Sabogal et al. found that as acculturation increased, familial obligations and family as referents decreased in respondents. Perceived family support scores, however, did not differ by acculturation level, place of birth or growing up, or generation.

Taken together, research about the importance of family suggests that familismo is a core Latino cultural value and that perceived support from family is a crucial component of this value that is not affected by acculturation level in adults (Marin \& Gamba, 2003; Sabogal et al., 1987). In addition, research about family with Latino youth has demonstrated a relationship between aspects of familism and a lower risk of substance abuse (Unger et al., 2002), lower juvenile delinquency rates (Pabon, 1998), and other harmful behaviors (Marin, 1993; Moore, 1970; Rodriguez \& Kosloski, 1998). Less is known, however, about the relationship between perceived family 
support and well-being and/or other positive psychological variables. Indeed, findings about family and various negative outcomes cannot be generalized to life satisfaction or well-being because well-being is more than just the absence of pathology or illness (Seligman, 2002). It is important to identify the variables that relate to positive outcomes in youth in addition to those that are related to negative outcomes and pathology (Gilman \& Huebner, 2003).

Life satisfaction, which has been identified as an individual's appraisal of his or her life, is a commonly used indicator of well-being. As the cognitive, judgmental component of subjective well-being (SWB; Diener, Suh, Lucas, \& Smith, 1999), life satisfaction can be distinguished from affective components of well-being (e.g., positive and negative affect), and thus transcends the immediate effects of mood states (Diener et al.). Life satisfaction appears to relate to important intra- and interpersonal outcomes (Gilman \& Huebner, 2000), and numerous studies with adults suggest that life satisfaction is associated with marital quality, social intimacy, work engagement, positive illusions, self-efficacy, optimism, and goal striving (Diener \& Suh, 2000; Myers \& Diener, 1995).

In contrast to the large body of literature about life satisfaction in adults, researchers are only beginning to understand life satisfaction among adolescents (Gilman \& Huebner, 2000). In a review of existing research, Gilman and Huebner (2003) noted that studies of adolescents have shown significant relationships between life satisfaction and positive and negative life experiences, parent-child conflict, substance use, stress and anxiety, and self-esteem in youth. Within minority or Latino youth specifically, less is known about life satisfaction and its correlates. Understanding this variable in the cultural contexts in which Latino adolescents live is important, as life satisfaction can be considered central to decisions that these youth may make about work, education, and relationships (Bradley \& Corwyn, 2004; Cooper, 1999; Romero \& Roberts, 2003). In addition, understanding the role of acculturation in these relationships also is warranted as the field begins to explore within-group differences in psychological functioning among Latino youth and families (Castañeda, 1994). 
Acculturation has been defined as the process of change that results from continuous contact between two different cultures (Berry, Trimble, \& Olmedo, 1986). Several models of acculturation have been proposed and used to guide measures of this construct. Most initial research about acculturation adopted a unidimensional approach, which situated Latino individuals, for example, on a continuum of acculturation between two opposite poles of European American and Latino culture. As individuals assimilated to mainstream culture, this model suggested that they moved toward the European American end of the continuum and away from their Latino culture. A limitation of this approach, however, was that there was no acknowledgment of the possibility that acculturation toward the dominant culture does not necessarily preclude the simultaneous retention of one's culture of origin (LaFromboise, Coleman, \& Gerton, 1993; Marin, 1992;

Szapocznik \& Kurtines, 1993; Zane \& Mak, 2003).

More recently, conceptualizations of acculturation have allowed for orthogonal, bidimensional measurements, such that acculturation to both Mexican and European American culture can be assessed independently along two axes (e.g., Cuellar, Arnold, \& Maldonado, 1995). Some researchers have integrated this approach into their measurement of acculturation (e.g., Cuellar et al., 1995; Marin \& Gamba, 1996) and, as such, have provided opportunities to investigate acculturation in a more complex manner and clarify how individuals can identify to differing degrees with both dominant culture and their cultures of origin (S. Sue, 2003). It has been suggested that researchers attend to acculturation as an important variable that can influence a group's values and that investigations of acculturation use more multidimensional conceptualizations in an effort to better understand cultural orientation and functioning (Berry, 2003; Chun \& Akutsu, 2003; Kim \& Abreu, 2001; Marin \& Gamba, 1996). In the case of Latino youth, therefore, an investigation of perceived family support and life satisfaction warrants consideration of acculturation level as a possible factor that influences the relationship of these variables.

\section{The Present Study}

The overall purpose of this study was to examine the relationship between perceived family support, acculturation, and life

Journal of Counseling Psychology, Vol. 53, No. 3 (July 2006): pg. 279-287. DOI. This article is (C American Psychological Association and permission has been granted for this version to appear in e-Publications@Marquette. American Psychological Association does not grant permission for this article to be further copied/distributed or hosted elsewhere without the express permission from American Psychological Association. 
satisfaction in Mexican American adolescents. Specifically, this study was designed to empirically test assumptions about the importance of perceived family support to life satisfaction in Mexican American youth and to address the following research questions: (a) What do Mexican American adolescents describe as variables that contribute to their life satisfaction? (b) How do perceived family support and acculturation relate to life satisfaction? and (c) Does acculturation moderate the relationship between perceived family support and life satisfaction?

To address these research questions, we used a mixed-methods approach combining both quantitative and qualitative methodologies. Several researchers have discussed the need for qualitative investigations of multicultural issues within psychology (Choudhuri, 2003; Morrow, Rakhsha, \& Castaneda, 2001; Ponterotto, 2002; Umaña-Taylor \& Bámaca, 2004), as they can provide an opportunity to better understand new phenomena or understudied populations without assuming that there is "one universal truth to be discovered" (Auerbach \& Silverstein, 2003, p. 26). Mixed-methods research may be particularly useful for gaining a more complex understanding of a particular topic while simultaneously testing theoretical models (Hanson, Creswell, Plano Clark, Petska, \& Creswell, 2005). Greene, Caracelli, and Graham (1989) suggested that mixed-methods studies can serve several purposes, including triangulation (seeking convergence of results), complementarity (examining overlapping or different facets of a phenomenon), initiation (discovering paradoxes and contradictions), development (using qualitative and quantitative methods sequentially), and expansion (adding breadth or scope to a project).

The present mixed-methods study was conceptualized from a pragmatic theoretical paradigm (Hanson et al., 2005; Tashakkori \& Teddlie, 1998). We conceptualized and designed the study as a dominantly quantitative, concurrent design, which is indicated by the following procedural notation (Morse, 1991): QUANT + qual. That is, both quantitative and qualitative data were collected at the same time, and the primary methodology was quantitative, with a lesser emphasis on the qualitative portion (Tashakkori \& Teddlie, 1998).

For our purposes, qualitative methodology was used to address the first research question, which sought to explore variables that 
youth described as contributing to their life satisfaction. Open-ended responses provided by participants were analyzed thematically by a collaborative research team, using several strategies from grounded theory methodology (Strauss \& Corbin, 1998), including open coding, category/theme generation, and exploring patterns across categories. Themes about factors that participants believed contributed to their life satisfaction were derived and described through this process. Quantitative methodology was used to answer the remaining research questions about the relationship between perceived family support, acculturation, and life satisfaction. We conducted a hierarchical multiple regression of perceived family support and Mexican and Anglo acculturation orientations on life satisfaction. We also added the interactions of perceived family support and both acculturation orientations to see whether these variables significantly predicted life satisfaction beyond the main effects of perceived family support and Mexican and Anglo orientations alone.

Findings from the quantitative and qualitative portions of the study were integrated to reveal areas of convergence as well as areas in which the data suggested discrepant findings or helped to provide a context for the data. Specifically, we sought to understand the relation between life satisfaction and perceived family support by looking for areas of convergence as well as complementarity between our qualitative and quantitative findings (Greene et al., 1989).

\section{Method}

\section{Participants}

Participants in this study were 309 English-speaking middle and high school students from California, Kansas, and Texas. Because there is research to suggest that grouping Latino adolescents into one collective ethnic group may not appropriately capture the within-group differences of this heterogeneous population (Umaña-Taylor \& Fine, 2001), only the participants who self-identified as Mexican American ( $n=293$ ) were included in the present study. Furthermore, the small number of middle-school students $(n=27)$ was removed in order to have a final sample with more homogeneity with respect to age group (e.g., all high school students). Of this final sample of 266 Mexican 
American high school students, 150 (56\%) were girls and $116(44 \%)$ were boys, and they had a mean age of 15.74 years $(S D=1.04$, range $=14-18$ years). The majority of the sample was Catholic (78\%), with $56 \%$ reporting that their parents had immigrated to the United States, and $26 \%$ reporting that their grandparents had immigrated to the United States.

\section{Procedure}

Potential participants were solicited in various ways, including contacting the League of United Latin American Citizens (LULAC) National Educational Service Centers, public and private schools, afterschool programs, and selected Federal TRIO (i.e., Upward Bound, Upward Bound Math/Science, and Educational Talent Search) programs. The primary researcher discussed the project with administrators and other staff to obtain initial approval to solicit participants and provided all the materials for the schools and organizations. In some cases, the primary researcher went to the sites to administer the surveys once parental consent forms were obtained, and in other cases, the site staff administered the surveys and returned them, along with the consent forms, to the researcher via mail. Several sites met with large groups of students on a regular basis (e.g., TRIO programs) and thus were able to monitor the return of informed consents in order to ensure maximum participation by students. For these sites, in addition to those from schools and community programs, the response rate was approximately $65 \%$. At one afterschool program, however, 100 consent forms were given to supervisors to pass out to students, and only 7 were returned. This was surprising considering the relatively high response rate we obtained from other sites, and we are unclear as to what extent the study was actually described to students as was intended at this particular program.

Packets containing two informed consent forms (one for the students/parents to keep and one to return to the investigator), as well as an introductory letter, were distributed to students to take home during school or during their program's activity time. Both consent forms and the letter were translated into Spanish such that all parents received copies in English and Spanish. Parents were asked to

Journal of Counseling Psychology, Vol. 53, No. 3 (July 2006): pg. 279-287. DOI. This article is (C American Psychological Association and permission has been granted for this version to appear in e-Publications@Marquette. American Psychological Association does not grant permission for this article to be further copied/distributed or hosted elsewhere without the express permission from American Psychological Association. 
send signed consent forms back to school (or the organization) with their children. Once consent was obtained from parents, students who volunteered to participate in the study were asked to complete a student assent form and then were administered a packet of materials during a 45-min period of school or of an afterschool program. Only students whose parents had provided consent and who had themselves completed an assent form were allowed to complete the packet of questionnaires, and the questionnaires were only provided in English. This decision to only sample students who were proficient readers in English was made during the development of the project because there was no existing data regarding the conceptual and functional equivalence of several of the measures for Latino adolescents in particular (American Psychological Association, 2002; Rogler, 1999).

\section{Instruments}

\section{Demographic questionnaire}

A demographic questionnaire was included to obtain participants' age, year in school, gender, race/ethnicity, generational status, and religious affiliation.

\section{Open-ended question about well-being}

At the bottom of the first page (demographic form) of each packet of measures was the following open-ended question: "What factors do you think contribute to life satisfaction and happiness?" Students were provided with 10 lines on which to write their responses and were encouraged to write on the back of the page if they needed more space.

\section{Perceived social support}

The Multidimensional Scale of Perceived Social Support (MSPSS; Zimet, Dahlem, Zimet, \& Farley, 1988) is a 12-item scale that measures perceived support from three domains: Family, Friends, and a Significant Other. Participants completing the MSPSS are asked to indicate their agreement with items on a 7-point Likert scale ranging 
from 1 (very strongly disagree) to 7 (very strongly agree). A sample item from the Family subscale is "I get the emotional help and support I need from my family." Support for the reliability and validity of the MSPSS has been found with samples of college students, adolescents living abroad, and adolescents on an inpatient psychiatry unit (CantyMitchell \& Zimet, 2000).

The MSPSS has been used in several studies with young adults and adults in the United States and in Europe (Kazarian \& McCabe, 1991; Zimet et al., 1988; Zimet, Powell, Farley, Werkman, \& Berkoff, 1990). In a recent study, Canty-Mitchell and Zimet (2000) investigated the MSPSS with a sample of urban adolescents, approximately $75 \%$ who were ethnic minority students. Results indicated internal reliability estimates of .93 for the total score, and .91, .89, and .91 for the Family, Friends, and Significant Other subscales. Factor analysis of the MSPSS with this sample confirmed the three-factor structure of the measure. In the present study, the four-item Perceived Support from Family subscale was used, and the internal reliability for this scale was .88.

\section{Life satisfaction}

The Multidimensional Students' Life Satisfaction Scale (MSLSS; Huebner, 1994) is a 47-item questionnaire that assesses life satisfaction in youth across six specific domains: Global, Family, Friends, School, Self, and Living Environment. The Global subscale, which comprises seven items, was used in the present study. Respondents were asked to rate items on a 6-point Likert scale ranging from 1 (strongly disagree) to 6 (strongly agree). A sample item from this subscale is "My life is going well."

Support for validity and reliability of the MSLSS has been found with various samples of children, middle- and high school students in the United States and Canada. The MSLSS was found to correlate with other measures of well-being, and its multidimensional factor structure was confirmed (Huebner, 1994; Gilman, Huebner, \& Laughlin, 2000). Internal reliability coefficients in various studies with the MSLSS ranged from .77 to .91 across all subscales. In the present study, the internal reliability was .86 for the Global subscale. 
NOT THE PUBLISHED VERSION; this is the author's final, peer-reviewed manuscript. The published version may be accessed by following the link in the citation at the bottom of the page.

\section{Acculturation level}

The Acculturation Rating Scale for Mexican Americans-II (ARSMA-II; Cuellar et al., 1995), which comprises 30 items, was used to measure acculturation in this study. Individuals were asked to respond to items about language preference, association, and identification with Mexican and Anglo cultures using a 5-point Likert scale ranging from 1 (not at all) to 5 (extremely often or almost always). The Mexican and Anglo subscales comprise 17 and 13 items, respectively. Examples of items from the Anglo and Mexican subscales are "I enjoy listening to English language music," and "I associate with Latinos and/or Latin Americans," respectively. In this study, we used Anglo and Mexican orientation subscales independently in order to evaluate their unique contributions to life satisfaction.

Studies with the ARSMA-II (Cuellar et al., 1995) revealed internal consistency estimates for the Anglo Orientation subscale (AOS) and the Mexican Orientation subscale (MOS) as .83 and .88, respectively. Flores and O'Brien (2002) reported reliability coefficients of .77 and .91 for the AOS and MOS with Mexican American adolescent women in particular. Test-retest reliability estimates, over a 2-week period, were .94 for the AOS and .96 for the MOS (Cuellar et al.). Internal reliability estimates of the Mexican and Anglo orientation scales in the present study were .88 and .67 , respectively.

\section{Results}

\section{Qualitative Analyses}

Qualitative analyses were originally conducted with responses from the total sample of both middle- and high school students, and findings were then revised and verified after the removal of the small sample of middle-school students. Of the 266 participants, 260 provided qualitative responses to the open-ended question, "What factors do you think contribute to life satisfaction and happiness?" Responses ranged from one word to short paragraphs of six sentences. In this study, we used several strategies from grounded theory (Strauss \& Corbin, 1998) to analyze these responses, including open 
NOT THE PUBLISHED VERSION; this is the author's final, peer-reviewed manuscript. The published version may be accessed by following the link in the citation at the bottom of the page.

coding, category/theme generation, and exploring patterns across categories.

Several strategies were used throughout the data analysis process to improve the rigor and "trustworthiness" of findings (Strauss \& Corbin, 1998). First, a collaborative team, comprising the primary researcher/Lisa $M$. Edwards (a biethnic Latina/White woman) and two undergraduate Mexican American students, was convened. An external auditor (a female European American graduate student) was asked to review emerging themes and reflect on the analysis process. A second external auditor (a male European American graduate student) was asked to review the findings with the primary researcher after the middle-school students had been removed in order to verify or revise the original themes. Our reviews indicated that the primary themes remained the same.

At the outset of data analysis, members of the research team discussed biases and assumptions, noting that they believed family, friends, and religious beliefs would be the most frequent responses reported by participants. Together, the research team then decided how the qualitative data might best be understood. They engaged in "open coding," or breaking down each participant's responses into words, phrases, or sentences that represented meaning units (Strauss \& Corbin, 1998). These meaning units were then labeled as concepts and were refined and discussed as necessary, eventually leading to a final list of concepts. The final concept list included the following terms: family, friends, attitude, faith (e.g., God, spirituality), love, money, helping others, work, home, education (e.g., teachers, school), physical health, and goals. Last, interrelated concepts were grouped together into larger category themes (e.g., descriptive sentences), and the most prominent themes were then selected and reviewed.

Results from this analysis suggested one primary, core theme, as well as two additional, smaller themes. The core theme that emerged from participants' open-ended responses was Family is important for providing support and love and included responses that described the significance of family and the ways in which family gives support and love to participants. Specifically, adolescents noted that their families provided unconditional care and encouragement as well

Journal of Counseling Psychology, Vol. 53, No. 3 (July 2006): pg. 279-287. DOI. This article is (C American Psychological Association and permission has been granted for this version to appear in e-Publications@Marquette. American Psychological Association does not grant permission for this article to be further copied/distributed or hosted elsewhere without the express permission from American Psychological Association. 
as affection and support. Illustrative quotes included the following: "Have a family that will be there for you and inspire you to be a better person in the future"; "Life satisfaction is to have your family be united and have love for one another in the home"; "Above all family, because how you enjoy life is being with those you care about"; "Having your family with you-they are the best that we could have"; "Having a caring family who supports you"; and "Family-especially my father who works hard to put food on the table everyday."

Two prominent additional themes emerged from the data as secondary to the importance of family. The first theme, Friends provide help and fun, revealed participants' beliefs that friends contributed to life satisfaction in several ways. Quotes describing the role of friends included "Having friends to talk to and hang around with, who will help you out"; "... good friends who can be relied on"; and "... kickin' it with my friends-going to school and talking to my homeboys."

The second additional theme that emerged from the qualitative data related to the contribution of a positive approach or attitude toward challenges. We labeled this theme The importance of a positive attitude toward life and problems. Illustrative quotes of this theme included "Always be optimistic - there will be ups and downs, but life will still go on"; "Life satisfaction comes when you are satisfied with who you are, but able to change what you can"; and "Do your besteven if you didn't win you could say that you tried your best."

\section{Quantitative Analyses}

Preliminary analyses included checking the data for outliers, normality, linearity, and homoscedasticity as well as examining potential differences on the basis of the location from which participants were sampled. The scatter plot of the studentized residuals against the predicted values of life satisfaction revealed no violations of assumptions of normality, linearity, and homoscedasticity. Results based on Cook and Weisberg's (1982) distance showed no serious outliers among the study variables (Tabachnick \& Fidell, 1996). Missing data points for an item on a subscale, which were found in 14 cases, were handled by substituting participants' subscale or mean scale scores for the missing value. 
Independent samples $t$ tests were conducted to see whether there were significant differences in the study variables for respondents who had completed surveys in California and Texas without the lead researcher present during administration $(n=184)$ and those that had completed surveys in Kansas administered by the lead researcher $(n=82)$. Results indicated that there were no significant differences in scores of life satisfaction, $t(262)=-1.65, p$ $=.10$; perceived family support, $t(261)=-0.32, p=.75$; Mexican orientation, $t(259)=-1.33, p=.19$; and Anglo orientation, $t(263)=$ $0.56, p=.58$. Because there were no differences in total scores on the basis of the location of participants, all the data in this sample were analyzed together.

The means, standard deviations, and zero-order correlations for all study variables (perceived family support, Anglo and Mexican orientations, and life satisfaction) are presented in Table 1. As can be seen, life satisfaction was significantly, positively correlated with perceived support from family and Mexican orientation. Thus, as scores of perceived family support and Mexican orientation increased, scores of global life satisfaction increased. Mexican and Anglo orientations also were significantly positively correlated with perceived family support; as scores on each of the acculturation orientations increased, perceived family support increased.

The main and interactive effects of Mexican and Anglo acculturation orientations and perceived family support on life satisfaction were assessed using hierarchical multiple regression procedures described by Cohen, West, and Aiken (2003) and Lubinski and Humphreys (1990). In order to reduce possible multicollinearity, scales were standardized before forming cross-product terms and before running the regression (Dunlap \& Kemery, 1987; Jaccard, Wan, \& Turrisi, 1990). Lubinski and Humphreys described procedures for the detection of spurious moderator effects, and they argued that moderator effects and quadratic trends are likely to share a large proportion of the variance. In other words, a significant interaction between two variables may be observed only because the effect is correlated substantially with quadratic trends of the component variables. Thus, entering quadratic trends into the regression equation reduces the possibility of observing such spurious moderators. 
In Lubinski and Humphrey's (1990) recommended procedure, main effects are entered first into the regression equation; after this a priori entry, quadratic trends are entered. In the first step, the main effects of perceived family support, Mexican orientation, and Anglo orientation were entered. Next, quadratic terms of the main effect variables were entered to control for spurious moderator effects. Finally, the two-way interactions of Mexican orientation and perceived family support, and Anglo orientation and perceived family support, were entered.

Table 2 provides the results of the multiple regressions involving our predictor variables. The main effects of perceived family support ( $\beta$ $=.50, p<.001)$ and Mexican orientation $(\beta=.12, p<.05)$ were significant at Step 1 , accounting for $28 \%$ of the variance in life satisfaction. Higher scores on the perceived family support and Mexican orientation variables were associated with higher life satisfaction. After controlling for quadratic trends (Step 2), the interactions between Anglo and Mexican orientations and perceived family support were not significant in Step 3, accounting for $1 \%$ of the variance in life satisfaction and resulting in a total $R^{2}=.29$.

\section{Discussion}

Because of the dearth of research examining well-being in Latino youth, the present mixed-methods study was conducted to expand researchers' understanding of the relationship between life satisfaction, acculturation, and perceived family support in Mexican American adolescents. A contribution of this study was that a mixedmethod approach was used to obtain qualitative perspectives on life satisfaction as well as quantitative findings about acculturation, perceived family support, and life satisfaction. An additional strength of this study was that acculturation was measured and conceptualized in a bidimensional manner, such that questions about the independent and interactive influences of both Mexican and Anglo orientations and family support on life satisfaction could be investigated (Zane \& Mak, 2003). Finally, rather than combining ethnic minority groups or Latino ethnic subgroups, or only sampling adults, we investigated Mexican American adolescents in particular (Castañeda, 1994; Umaña-Taylor \& Fine, 2001). 
NOT THE PUBLISHED VERSION; this is the author's final, peer-reviewed manuscript. The published version may be accessed by following the link in the citation at the bottom of the page.

\section{Integration of Mixed-Methods Findings}

The quantitative and qualitative results converged to provide additional empirical support for the importance of family in the lives of Mexican American adolescents (Marin \& Gamba, 2003; Paniagua, 1998; Vazquez Garcia et al., 2000). The qualitative findings suggested that youth identified their family as most important in contributing to their life satisfaction above other factors such as friends, religion, or money. In addition, the qualitative findings suggested that the important role of family was to provide support specifically. These findings also suggest that previous research with adults about perceived support as the critical aspect of familismo may also apply to youth (Sabogal et al., 1987).

Two additional themes that emerged from our qualitative data, Friends provide help and fun and The importance of a positive attitude toward life and problems, suggested aspects of participants' lives that were important to them, though not as critical as family. These additional findings, though not able to be explored by quantitative analyses in this particular study, help to identify additional factors that contribute to life satisfaction from the perspective of Mexican American youth and can be included in future models of life satisfaction.

The quantitative findings about the relationship between perceived family support and acculturation orientations revealed additional information regarding the role of these variables in predicting overall life satisfaction in Mexican American youth. Mexican orientation, but not Anglo orientation, was significantly associated with life satisfaction in this sample, highlighting the importance of investigating acculturation orientations separately (Kim \& Abreu, 2001; Marin \& Gamba, 2003). As noted by Ruelas, Atkinson, and Ramos-Sanchez (1998) in their study of counselor credibility, unidimensional measures of acculturation may lead to inaccurate inferences about cultural orientation. These authors used the ARSMAII (Cuellar et al., 1995) and found that Mexican orientation scores were significantly related to credibility of counselors, but not Anglo scores. Although we investigated a different dependent variable, the findings were similar in that Mexican orientation appeared to be the influential acculturation orientation. Future studies about life 
NOT THE PUBLISHED VERSION; this is the author's final, peer-reviewed manuscript. The published version may be accessed by following the link in the citation at the bottom of the page.

satisfaction in Mexican American youth should explore why Mexican orientation, in contrast to Anglo orientation, plays this important role.

\section{Limitations, Directions for Future Research, and Implications}

There are several limitations to this study that should be noted. In the qualitative portion of the study, it was not clear whether the open-ended question that was presented to students was understood in the same way by each of the respondents. Furthermore, the question did not ask for an evaluation of participants' life satisfaction. It is possible, therefore, that participants interpreted this question to address factors that contribute to life satisfaction for people in general. The study also was limited in that only English-speaking participants were allowed to participate. By not including Spanish-speaking adolescents, and by recruiting most participants from educational and cultural programs (e.g., TRIO programs and the like), we may have limited the representativeness of the sample across acculturation levels and degree of educational involvement.

One avenue for potential future investigation lies in understanding different types of social support that Latino adolescents use or perceive in their lives. In the present study, only general perceived family support was assessed, and we were unable to measure how specific types of support may contribute to life satisfaction in these youth. A useful conceptualization of social support was proposed by Weiss (1974), who described provisions that can result from relationships with others, such as guidance, reliable alliance, attachment, reassurance of worth, social integration, and opportunity to provide nurturance. This framework has been used and operationalized by many researchers (Aquino, Russell, Cutrona, \& Altmaier, 1996; Cutrona \& Russell, 1987) and can provide a beginning structure for researchers to probe more specific types of social support in Latino youth.

In addition, investigating variables such as perceived support from family and acculturation and life satisfaction over time, rather than only focusing on cross-sectional views, also will provide additional information about the changing role of family and its influence on the

Journal of Counseling Psychology, Vol. 53, No. 3 (July 2006): pg. 279-287. DOI. This article is (C American Psychological Association and permission has been granted for this version to appear in e-Publications@Marquette. American Psychological Association does not grant permission for this article to be further copied/distributed or hosted elsewhere without the express permission from American Psychological Association. 
well-being of Latino youth as they transition into adulthood (Chun \& Akutsu, 2003; Marin \& Gamba, 2003). The changing demographics of our present society, as well as the demands on the lives of adolescents, require closer investigations of how the function and role of various resources such as family adapt over time and how acculturation (e.g., Mexican orientation) influences this process.

The increasing presence of Mexican American youth in our schools and communities requires that counseling psychologists purposefully work to understand these adolescents' experience of life satisfaction in addition to obstacles that may be hindering their wellbeing. Low educational attainment as well as problems such as gang involvement, substance abuse, and teenage pregnancy have been identified as significant concerns faced by Latino youth (Chavez \& Roney, 1990), and scholars have noted that few mental health professionals are trained to work with Mexican American adolescents (Castañeda, 1994). Investigating within-group variability in the experience of life satisfaction and the role of perceived family support, such as the analyses in the present study, provide a more balanced and detailed portrait of functioning within Latino adolescents (Villarruel \& Montero-Sieburth, 2000). Our findings suggest that family and Mexican orientation will be particularly important variables for counseling psychologists to consider when working to promote life satisfaction with Mexican American youth. Future research can continue to elucidate strengths and assets within this important population and contribute to a growing body of knowledge about youth resources.

\section{Footnotes}

${ }^{1}$ In this article, the terms Latino and Hispanic have been used interchangeably. Specifically, in cases in which research is summarized, the descriptors used by the authors were retained. The participant sample, however, was restricted to adolescents who self-identified as "Mexican" or "Mexican American" and are thus described as such. 
NOT THE PUBLISHED VERSION; this is the author's final, peer-reviewed manuscript. The published version may be accessed by following the link in the citation at the bottom of the page.

\section{References}

American Psychological Association. (2002). Guidelines on multicultural education, training, research, practice, and organizational change for psychologists. Washington DC: Author.

Aquino, J. A., Russell, D., Cutrona, C. E., \& Altmaier, E. M. (1996). Employment status, social support, and life satisfaction among the elderly. Journal of Counseling Psychology, 43, 480-489.

Auerbach, C. F., \& Silverstein, L. B. (2003). Qualitative data: An introduction to coding and analysis. New York: NYU Press.

Berry, J. W. (2003). Conceptual approaches to acculturation. In K. M.Chun, P. B.Organista, \& G.Marin (Eds.), Acculturation: Advances in theory, measurement, and applied research (pp. 17-37). Washington, DC: American Psychological Association.

Berry, J. W., Trimble, J. E., \& Olmedo, E. L. (1986). Assessment of acculturation. In W. J.Lonner \& J. W.Berry (Eds.), Field methods in cross-cultural research (pp. 291-345). Beverly Hills, CA: Sage.

Bradley, R. H., \& Corwyn, R. F. (2004). Life satisfaction among European American, African American, Chinese American, Mexican American, and Dominican American adolescents. International Journal of Behavioral Development, 28, 385-400.

Canty-Mitchell, J., \& Zimet, G. D. (2000). Psychometric properties of the Multidimensional Scale of Perceived Social Support in urban adolescents. American Journal of Community Psychology, 28, 391400.

Castañeda, D. M. (1994). A research agenda for Mexican-American adolescent mental health. Adolescence, 29, 225-240.

Castillo, L. G., Conoley, C. W., \& Brossart, D. F. (2004). Acculturation, White marginalization, and family support as predictors of perceived distress in Mexican American female college students. Journal of Counseling Psychology, 51, 151-157.

Chavez, J. M., \& Roney, C. E. (1990). Psychocultural factors affecting the mental health status of Mexican American adolescents. In A.

Journal of Counseling Psychology, Vol. 53, No. 3 (July 2006): pg. 279-287. DOI. This article is (C American Psychological Association and permission has been granted for this version to appear in e-Publications@Marquette. American Psychological Association does not grant permission for this article to be further copied/distributed or hosted elsewhere without the express permission from American Psychological Association. 
NOT THE PUBLISHED VERSION; this is the author's final, peer-reviewed manuscript. The published version may be accessed by following the link in the citation at the bottom of the page.

R.Stiffman \& L. E.Davis (Eds.), Ethnic issues in adolescent mental health (pp. 73-91). Newbury Park, CA: Sage.

Choudhuri, D. D. (2003). Qualitative research and multicultural counseling competency. In D. B.Pope-Davis, H. L. K.Coleman, W. M.Liu, \& R. L.Toporek (Eds.), Handbook of multicultural competencies in counseling and psychology (pp. 267-282). Thousand Oaks, CA: Sage.

Chun, K. M., \& Akutsu, P. D. (2003). Acculturation among ethnic minority families. In K. M.Chun, P. B.Organista, \& G.Marin (Eds.), Acculturation: Advances in theory, measurement and applied research (pp. 95-119). Washington, DC: American Psychological Association.

Cohen, J., West, S. G., \& Aiken, L. S. (2003). Applied multiple regression/correlation analysis for the behavioral sciences (3rd ed.). Mahwah, NJ: Erlbaum.

Cook, R. D., \& Weisberg, S. (1982). Residuals and influence in regression. New York: Chapman \& Hall.

Cooper, G. R. (1999). Multiple selves, multiple worlds: Cultural perspectives on individuality and connectedness in adolescent development. In A. S.Masten (Ed.), Cultural process in child development (pp. 25-57). Mahwah, NJ: Erlbaum.

Cuellar, I., Arnold, B., \& Maldonado, R. (1995). Acculturation Rating Scale for Mexican Americans-II: A revision of the original ARSMA Scale. Hispanic Journal of Behavioral Sciences, 17, 275-304.

Cutrona, C. E., \& Russell, D. (1987). The provisions of social relationships and adaptation to stress. In W. H.Jones \& D.Perlman (Eds.), Advances in personal relationships (Vol. 1, pp. 37-68). Greenwich, CT: JAI Press.

Diener, E., \& Suh, E. M. (2000). Measuring subjective well-being to compare the quality of life of cultures. In E.Diener \& E. M.Suh (Eds.), Culture and subjective well-being (pp. 3-12). Cambridge, MA: MIT Press.

Diener, E., Suh, E. M., Lucas, R., \& Smith, H. (1999). Subjective well-being: Three decades of progress. Psychological Bulletin, 125, 276-302.

Dunlap, W. P., \& Kemery, E. R. (1987). Failure to detect moderating effects: Is multicollinearity the problem?Psychological Bulletin, 102, 418-420.

Journal of Counseling Psychology, Vol. 53, No. 3 (July 2006): pg. 279-287. DOI. This article is (C American Psychological Association and permission has been granted for this version to appear in e-Publications@Marquette. American Psychological Association does not grant permission for this article to be further copied/distributed or hosted elsewhere without the express permission from American Psychological Association. 
NOT THE PUBLISHED VERSION; this is the author's final, peer-reviewed manuscript. The published version may be accessed by following the link in the citation at the bottom of the page.

Flores, L. Y., \& O'Brien, K. M. (2002). The career development of Mexican American adolescent women: A test of social cognitive career theory. Journal of Counseling Psychology, 49, 14-27.

Gaines, S. O., Marelich, W. D., Bledsoe, K. L., Steers, W. N., Henderson, M. C., Granrose, C. S., et al. (1997). Links between race/ethnicity and cultural values as mediated by racial/ethnic identity and moderated by gender. Journal of Personality and Social Psychology, 72, 1460-1476.

Gilman, R., \& Huebner, E. S. (2000). Review of life satisfaction measures for adolescents. Behaviour Change, 17, 178-195.

Gilman, R., \& Huebner, E. S. (2003). A review of life satisfaction research with children and adolescents. School Psychology Quarterly, 18, 192205.

Gilman, R., Huebner, E. S., \& Laughlin, J. (2000). A first study of the Multidimensional Students' Life Satisfaction Scale with adolescents. Social Indicators Research, 52, 135-160.

Greene, J. C., Caracelli, V. J., \& Graham, W. F. (1989). Toward a conceptual framework for mixed-method evaluation designs. Educational Evaluation and Policy Analysis, 11, 255-274.

Hanson, W. E., Creswell, J. W., Plano Clark, V. L., Petska, K. S., \& Creswell, J. D. (2005). Mixed methods research designs in counseling psychology. Journal of Counseling Psychology, 52, 224-235.

Huebner, E. S. (1994). Preliminary development and validation of a multidimensional life satisfaction scale for children. Psychological Assessment, 6, 149-158.

Jaccard, J., Wan, C. K., \& Turrisi, R. (1990). The detection and interpretation of interaction effects between continuous variables in multiple regression. Multivariate Behavioral Research, 25, 467-478.

Kazarian, S. S., \& McCabe, S. B. (1991). Dimensions of social support in the MSPSS: Factorial structure, reliability, and theoretical implications. Journal of Community Psychology, 19, 150-160.

Kim, B. S. K., \& Abreu, J. M. (2001). Acculturation measurement. In J. G.Ponterotto, J. M.Casas, L. A.Suzuki, \& C. M.Alexander (Eds.),

Journal of Counseling Psychology, Vol. 53, No. 3 (July 2006): pg. 279-287. DOI. This article is @ American Psychological Association and permission has been granted for this version to appear in e-Publications@Marquette. American Psychological Association does not grant permission for this article to be further copied/distributed or hosted elsewhere without the express permission from American Psychological Association. 
NOT THE PUBLISHED VERSION; this is the author's final, peer-reviewed manuscript. The published version may be accessed by following the link in the citation at the bottom of the page.

Handbook of multicultural counseling (pp. 394-424). Thousand Oaks, CA: Sage.

Knight, G. P., Bernal, M. E., Cota, M. K., Garza, C. A., \& Ocampo, K. A. (1993). Family socialization and Mexican American identity and behavior. In M. E.Bernal \& G. P.Knight (Eds.), Ethnic identity (pp. 105-129). New York: SUNY Press.

LaFromboise, T., Coleman, H., \& Gerton, J. (1993). Psychological impact of biculturalism: Evidence and theory. Psychological Bulletin, 114, 395412.

Lopez, S. J., Magyar-Moe, J. L., Petersen, S. E., Ryder, J. A., Krieshok, T. S., O'Byrne, K. K., et al. (2006). Contextualizing human strengths: A counseling psychology agenda for increasing the applicability of positive psychology. The Counseling Psychologist, 34, 205-227.

Lopez, S. J., Prosser, E. C., Edwards, L. M., Magyar-Moe, J. L., Neufeld, J. E., \& Rasmussen, H. N. (2002). Putting positive psychology in a multicultural context. In C. R.Snyder \& S. J.Lopez (Eds.), Handbook of positive psychology (pp. 700-714). New York: Oxford University Press.

Lubinski, D., \& Humphreys, L. G. (1990). Assessing spurious "moderator effects": Illustrated substantively with the hypothesized ("synergistic") relation between spatial and mathematical ability. Psychological Bulletin, 107, 385-393.

Marin, G. (1992). Issues in the measurement of acculturation among Hispanics. In K. F.Geisinger (Ed.), Psychological testing of Hispanics (pp. 235-251). Washington, DC: American Psychological Association.

Marin, G. (1993). Influence of acculturation on familialism and selfidentification among Hispanics. In M. E.Bernal \& G. P.Knight (Eds.), Ethnic identity (pp. 181-196). New York: SUNY Press.

Marin, G., \& Gamba, R. J. (1996). A new measurement of acculturation for Hispanics: The Bidimensional Acculturation Scale for Hispanics (BAS). Hispanic Journal of Behavioral Sciences, 18, 297-316.

Marin, G., \& Gamba, R. J. (2003). Acculturation and changes in cultural values. In K. M.Chun, P. B.Organista, \& G. Marin (Eds.), Acculturation: Advances in theory, measurement, and applied research (pp. 83-94). Washington, DC: American Psychological Association.

Journal of Counseling Psychology, Vol. 53, No. 3 (July 2006): pg. 279-287. DOI. This article is (C American Psychological Association and permission has been granted for this version to appear in e-Publications@Marquette. American Psychological Association does not grant permission for this article to be further copied/distributed or hosted elsewhere without the express permission from American Psychological Association. 
NOT THE PUBLISHED VERSION; this is the author's final, peer-reviewed manuscript. The published version may be accessed by following the link in the citation at the bottom of the page.

Mindel, C. H. (1980). Extended familism among urban Mexican Americans, Anglos and Blacks. Hispanic Journal of Behavioral Sciences, 2, 21-34.

Moore, J. W. (1970). Mexican Americans. Englewood Cliffs, NJ: Prentice Hall.

Morrow, S. L., Rakhsha, G., \& Castaneda, C. L. (2001). Qualitative research methods for multicultural counseling. In J. G.Ponterotto, J. M.Casas, L. A.Suzuki, \& C. M.Alexander (Eds.), Handbook of multicultural counseling (pp. 575-603). Thousand Oaks, CA: Sage.

Morse, J. M. (1991). Approaches to qualitative-quantitative methodological triangulation. Nursing Research, 40, 120-123.

Myers, D. G., \& Diener, E. (1995). Who is happy?Psychological Science, 6, 10-19.

Pabon, E. (1998). Hispanic adolescent delinquency and the family: A discussion of sociocultural influences. Adolescence, 33, 941-955.

Paniagua, F. (1998). Assessing and treating culturally diverse clients: $A$ practical guide. Thousand Oaks, CA: Sage.

Ponterotto, J. G. (2002). Qualitative research methods: The fifth force in psychology. The Counseling Psychologist, 30, 394-406.

Rodriguez, J. M., \& Kosloski, K. (1998). The impact of acculturation on attitudinal familism in a community of Puerto Rican Americans. Hispanic Journal of Behavioral Sciences, 20, 375-390.

Rodriguez, M. C., \& Morrobel, D. (2004). A review of Latino youth development research and a call for an asset orientation. Hispanic Journal of Behavioral Sciences, 26, 107-127.

Rogler, L. H. (1999). Methodological sources of cultural insensitivity in mental health research. American Psychologist, 54, 424-433.

Romero, A. J., \& Roberts, R. E. (2003). Stress within a bicultural context for adolescents of Mexican descent. Cultural Diversity \& Ethnic Minority Psychology, 9, 171-184.

Ruelas, S. R., Atkinson, D. R., \& Ramos-Sanchez, L. (1998). Counselor helping model and participant ethnicity, locus of control, and perceived counselor credibility. Journal of Counseling Psychology, 45, 98-103.

Journal of Counseling Psychology, Vol. 53, No. 3 (July 2006): pg. 279-287. DOI. This article is @ American Psychological Association and permission has been granted for this version to appear in e-Publications@Marquette. American Psychological Association does not grant permission for this article to be further copied/distributed or hosted elsewhere without the express permission from American Psychological Association. 
NOT THE PUBLISHED VERSION; this is the author's final, peer-reviewed manuscript. The published version may be accessed by following the link in the citation at the bottom of the page.

Sabogal, F., Marin, G., Otero-Sabogal, R., Marin, B. V., \& Perez-Stable, E. J. (1987). Hispanic familism and acculturation: What changes and what doesn't?Hispanic Journal of Behavioral Sciences, 9, 397-412.

Seligman, M. E. P. (2002). Positive psychology, positive prevention, and positive therapy. In C. R.Snyder \& S. J.Lopez (Eds.), Handbook of positive psychology (pp. 3-9). New York: Oxford University Press.

Strauss, A., \& Corbin, J. (1998). Basics of qualitative research: Techniques and procedures for developing grounded theory (2nd ed.). Thousand Oaks, CA: Sage.

Sue, D. W., \& Constantine, M. G. (2003). Optimal human functioning in people of color in the United States. In B. W.Walsh (Ed.), Counseling psychology and optimal human functioning (pp. 151-169). Mahwah, NJ: Erlbaum.

Sue, S. (2003). Foreword. In K. M.Chun, P. B.Organista, \& G.Marin (Eds.), Acculturation: Advances in theory, measurement, and applied research (pp. xvii-xxi). Washington, DC: American Psychological Association.

Super, D. E. (1955). Transition: From vocational guidance to counseling psychology. Journal of Counseling Psychology, 2, 3-9.

Szapocznik, J., \& Kurtines, W. (1993). Family psychology and cultural diversity. American Psychologist, 48, 400-407.

Tabachnick, B. G., \& Fidell, L. S. (1996). Using multivariate statistics (3rd ed.). New York: HarperCollins.

Tashakkori, A., \& Teddlie, C. (1998). Mixed methodology. Thousand Oaks, CA: Sage.

Triandis, H. C., Marin, G., Betancourt, J., Lisansky, J., \& Chang, B. (1982). Dimensions of familism among Hispanic and mainstream Navy recruits. Chicago: Department of Psychology, University of Illinois.

Tyler, L. E. (1973). Design for a hopeful psychology. American Psychologist, 28, 1021-1029.

Umaña-Taylor, A. J., \& Bámaca, M. Y. (2004). Conducting focus groups with Latino populations: Lessons from the field. Family Relations, 53, 261272.

Journal of Counseling Psychology, Vol. 53, No. 3 (July 2006): pg. 279-287. DOI. This article is (C American Psychological Association and permission has been granted for this version to appear in e-Publications@Marquette. American Psychological Association does not grant permission for this article to be further copied/distributed or hosted elsewhere without the express permission from American Psychological Association. 
NOT THE PUBLISHED VERSION; this is the author's final, peer-reviewed manuscript. The published version may be accessed by following the link in the citation at the bottom of the page.

Umaña-Taylor, A. J., \& Fine, M. A. (2001). Methodological implications of grouping Latino adolescents into one collective ethnic group. Hispanic Journal of Behavioral Sciences, 23, 347-362.

Unger, J. B., Ritt-Olson, A., Teran, L., Huang, T., Hoffman, B. R., \& Palmer, P. (2002). Cultural values and substance use in a multiethnic sample of California adolescents. Addiction Research \& Theory, 10, 257-279.

U. S. Census Bureau. (2000). Annual projections of the resident population by age, sex, race, and Hispanic origin: Lowest, middle, highest series and zero international migration series, 1999 to 2100. Retrieved October 7, 2002, from http://www census.gov/population/www/projections/natdet-D1A.html

U. S. Census Bureau. (2001). The Hispanic population: Census 2000 brief. Washington, DC: U.S. Department of Commerce, Economics and Statistical Administration.

Vazquez Garcia, H. A., Garcia Coll, C., Erkut, S., Alarcon, O., \& Tropp, L. R. (2000). Family values of Latino adolescents. In M.Montero-Sieburth \& F. A.Villarruel (Eds.), Making invisible Latino adolescents visible (pp. 239-263). New York: Falmer Press.

Villarruel, F. A., \& Montero-Sieburth, M. (2000). Latino youth and America. In M.Montero-Sieburth \& F. A.Villarruel (Eds.), Making invisible Latino adolescents visible (pp. xiii-xxxii). New York: Falmer Press.

Walsh, W. B. (Ed.). (2003). Counseling psychology and optimal human functioning. Mahwah, NJ: Erlbaum.

Weiss, R. S. (1974). The provisions of social relationships. In Z.Rubin (Ed.), Doing unto others (pp. 17-26). Englewood Cliffs, NJ: Prentice Hall.

Zane, N., \& Mak, W. (2003). Major approaches to the measurement of acculturation among ethnic minority populations: A content analysis and an alternative empirical strategy. In K. M.Chun, P. B.Organista, \& G. Marin (Eds.), Acculturation: Advances in theory, measurement, and applied research (pp. 39-60). Washington, DC: American Psychological Association.

Zimet, G. D., Dahlem, N. W., Zimet, S. G., \& Farley, G. K. (1988). The Multidimensional Scale of Perceived Social Support. Journal of Personality Assessment, 52, 30-41.

Journal of Counseling Psychology, Vol. 53, No. 3 (July 2006): pg. 279-287. DOI. This article is (C American Psychological Association and permission has been granted for this version to appear in e-Publications@Marquette. American Psychological Association does not grant permission for this article to be further copied/distributed or hosted elsewhere without the express permission from American Psychological Association. 
NOT THE PUBLISHED VERSION; this is the author's final, peer-reviewed manuscript. The published version may be accessed by following the link in the citation at the bottom of the page.

Zimet, G. D., Powell, S. S., Farley, G. K., Werkman, S., \& Berkoff, K. A. (1990). Psychometric characteristics of the Multidimensional Scale of Perceived Social Support. Journal of Personality Assessment, 55, 610617.

\section{Appendix}

Table I

Means, Standard Deviations, and Correlations Among Variables $(N=266)$

\begin{tabular}{lrccc}
\hline \multicolumn{1}{c}{ Variable } & 1 & 2 & 3 & 4 \\
\hline 1. Life satisfaction & - & $.53^{* * *}$ & \multicolumn{1}{c}{.07} & $.22^{* * *}$ \\
2. Perceived family support & & - & $.15^{*}$ & $.21^{* 8}$ \\
3. Anglo orientation & & & - & .07 \\
4. Mexican orientation & 27.27 & 47.95 & 19.88 & 26.74 \\
$M$ & 8.21 & 8.40 & 13.35 & 16.92 \\
$S D$ & & & & \\
\hline
\end{tabular}

$* p<.05 . * * p<.01, * * * p<.001$.

Table 2

Summary of Hierarchical Regression Analysis of Perceived Family Support, Mexican, and Anglo Orientations as Predictors of Life Satisfaction $(N=266)$

\begin{tabular}{|c|c|c|c|c|c|c|c|c|c|}
\hline Variable & $B$ & $S E B$ & $\beta$ & $t$ & $d f$ & $R^{2}$ & $\Delta R^{2}$ & $\Delta F$ & $d f$ \\
\hline Step 1 (main effects) & & & & & 254 & 0.28 & 0.28 & 32.17 काष & 3,254 \\
\hline Perceived family support & 0.51 & 0.07 & .51 & $7.01^{\text {*a*k }}$ & & & & & \\
\hline Anglo orientation & 0.00 & 0.06 & .00 & 0.02 & & & & & \\
\hline Mexican orientation & 0.13 & 0.06 & .13 & $2.05^{\circ}$ & & & & & \\
\hline Step 2 (quadratic effects) & & & & & 251 & 0.28 & 0.00 & 0.1 & 3. 251 \\
\hline Step 3 (interaction effects) & & & & & 249 & 0.29 & 0.01 & 1.98 & 2. 249 \\
\hline Perceived family support & 0.51 & 0.07 & .51 & $7.01^{\text {क्षा }}$ & & & & & \\
\hline Anglo orientation & 0.00 & 0.06 & .00 & 0.02 & & & & & \\
\hline Mexican orientation & 0.13 & 0.06 & .13 & $2.05^{\circ}$ & & & & & \\
\hline Family squared & 0.00 & 0.05 & 00 & 0.02 & & & & & \\
\hline Anglo squared & 0.04 & 0.04 & .05 & 0.82 & & & & & \\
\hline Mexican squared & 0.02 & 0.05 & .03 & 0.43 & & & & & \\
\hline Anglo $\times$ Family & -0.07 & 0.06 & -.07 & -1.20 & & & & & \\
\hline Mexican $\times$ Family & -0.11 & 0.06 & -.11 & -1.86 & & & & & \\
\hline
\end{tabular}

${ }^{*} p<.05 . \quad{ }^{* *} p<.01 . \quad * * * p<.001$.

Journal of Counseling Psychology, Vol. 53, No. 3 (July 2006): pg. 279-287. DOI. This article is @ American Psychological Association and permission has been granted for this version to appear in e-Publications@Marquette. American Psychological Association does not grant permission for this article to be further copied/distributed or hosted elsewhere without the express permission from American Psychological Association. 